\title{
Corporate Customers' Adoption of Internet Banking: Case of Klang Valley Business Firm in Malaysia
}

\author{
Syed Shah Alam (Corresponding author) \\ Faculty of Business Management, Universiti Teknologi MARA \\ 40450 Shah Alam, Selangor \\ Tel: 60-3- 5544- 4708 E-mail: syedshah@salam.uitm.edu.my \\ Rosidah Musa \\ Faculty of Business Management, Universiti Teknologi MARA \\ 40450 Shah Alam, Selangor \\ Tel: 60-3- 5544- 4715 E-mail: roshidahm@salam.uitm.edu.my \\ Faridah Hassan \\ Faculty of Business Management, Universiti Teknologi MARA \\ 40450 Shah Alam, Selangor \\ Tel: 60-3- 5544- 4760 E-mail: faridah387@salam.uitm.edu.my
}

\begin{abstract}
This paper summarizes academic literature on Internet banking drivers and found that there is a need to conduct research on corporate customer Internet banking adoption behaviour. The empirical data were collected from a questionnaire survey of 223 business firms selected from the telephone directory in Klang Valley area in Malaysia. This study examines the relationship between Internet banking adoption and its six factors, namely awareness, ease of use, security, cost, reluctance to change and accessibility. The results of this study show that four factors examined are significantly important to the adoption of Internet banking. However, perceive ease of use and reluctant to change are found to be insignificant in determining its adoption. This study provides insightful understanding of corporate customer's perception about Internet banking adoption in their banking transactions. Banks are interested in promoting online business may find these findings helpful in guiding their efforts.
\end{abstract}

Keywords: Internet banking, Corporate customers, Klang Valley, Malaysia

\section{Introduction}

Since the new millennium, Internet banking has experienced explosive growth in many countries and transformed traditional banking practice. Internet banking has changes the way of services provided by the banking sectors to their customers. By offering Internet banking services, traditional financial institutions seek to lower operating costs, improve customer banking services, retain customer, reduce their branch networks, and downsize the number of their service staff (Parisa, 2006).

Pang (1995) reported that the electronic banking started in Malaysia in 1970's. Automated Teller Machines (ATM) is the first electronic innovation used by the Malaysian banks in 1981. The ATMs to a large extent released banks from the constraints of time and geographical location. They presented banks with a more economical substitute for brick and mortar branches. Central Bank of Malaysia had given permission to the local bank to offer Internet banking services $1^{\text {st }}$ June 2000. On $15^{\text {th }}$ of June in 2000 Maybank, one of the pioneer bank in Malaysia offer Internet banking in Malaysia through its website www.maybank2u.com. The services provided to the consumers are banking enquiry functions, bill payment, credit card payment, fund transfers, account summary as well as on transaction history. Customer services are provided via e-mail as well as via telephone line are available from 6AM to 12 mid-nights. 
A review of the Malaysian banking sites in the Internet revealed that all domestic banks, which have been accorded an anchor bank status by the Central bank, have web presence. Almost all banks in Malaysia have web presence and yet to commence their Internet banking operations.

\section{Impact of Internet Banking on Customers}

Customers are expected to enjoy several benefits as a result of the implementation of Internet banking. Chan (2001) stated convenience as one of them. Johnson et al (1995) agrees that convenience is an important factor to customers. Devlin (1995) found that customers are now demanding greater conveniences and accessibility. This is reflected in longer branch banking hours and an increase in the choice of delivery mechanisms.

Baldock (1997) found that the implementation of Internet banking would remove the constraints of time, place and form. The reason is that transactions can be conducted from anywhere and anytime as long as they have access to a computer and connection to the Internet as banks would be "open" 24 hours a day and 7 days in a week (Chan, 2001; Johnson et al., 1995; Jeon and Rice, 1997; Baldock, 1997).

Birch and Young, (1997) asserted that consumers would also enjoy the privilege of access to far more providers of financial services. As a result of a wider choice of Internet bank service providers, the costs searching, negotiating and concluding deals will be lower as the comparison of products and services would be made easier over the Internet (Bakos, 1991; Malone et al., 1989, Peters, 1998). Information on pricing and returns is also far easier to gather (Birch and Young, 1997).

Chan (2001) also quoted that customers will be able to save of traveling to the branch and other intangible factors like avoiding the aggravation of traffic jams and long queues as the advantages of Internet banking. He also stated that with certain browsers, the "autofill" feature will help save time because frequently visited website addresses, login names and passwords need not be typed over and over again. Indeed Birch and Young (1997) highlighted, customers will be able to conduct their banking transactions at ease, because they would not be subjected to high-pressure sales tactics.

\section{Problem Statement}

This study focuses on the adoption of Internet banking services by corporate customers in Malaysia and aims to gain a deeper understanding of the factors influencing the adoption of Internet banking services by Malaysian, particularly in Klang Valley customers. The research question for this research can be formulated as:

What are main factors, which influence the adoption of Internet banking services?

In this context, the factors that affect the adoption rate of Internet banking which were considered in this study are listed as follows:

the awareness of the services and its benefits;

the ease of use;

the safety and security of transacting over the Internet ;

the cost of using Internet banking;

the reluctance to change from current traditional banking, and ;

the access to computer or Internet.

To this end, options were gathered from a broad base community in the Klang Valley paying particular attention to business customers of the banks. The Klang Valley is chosen as this is one of the most developed business and financial centre in the country. The focus of this research will be particularly to provide both bankers and policy makers with public opinion that could assist in the understanding and appreciation of the factors that affect the adoption of Internet banking in Malaysia, particularly in Klang Valley.

\section{Factors affecting the Internet Banking Adoption}

Sathye (1999) defines adoption as "the acceptance and continued use of a product, service or idea." The critical question is whether customers will accept the electronic form of receiving information and performing transactions. In the study of Ernst and Young (1998) found that financial institutions are not sure about customer acceptance of E-commerce and evidence shows that 3\% of Malaysian doing online retail transactions. Moreover, Mols et al. (1999) study reveals that the diffusion of electronic banking is more determined by customer's acceptance than by the seller offerings.

Davidson (1998) study found that there is little evidence of consumer demand for Internet banking services. Among the factors influencing the non-adoption of Internet banking by customers include the desire for personal interaction with banking staff, technology phobia, widespread network of existing branches and also low computer literacy among customers (Mols et al., 1999). O'Connell (1996) demonstrated that the explanation for slow growth of Internet banking is caused by security concerns, lack of knowledge about availability of such a service, Internet banking sites being not 
user-friendly and the lack of access to computers or the Internet. In this study six factors such as awareness, ease of use, safety and security, cost of Internet banking, reluctance and lack of computer or Internet access are focused. This is inline with Wallis (1997) whose report states that new technology adoption by the majority of the customers depends mainly on these factors.

\subsection{Awareness}

Adoption can be defined as the acceptance and continued use of a product, service or and idea. According to Rogers and Shoemaker (1971), consumers go through "a series of process in knowledge, conviction, decision and confirmation" before they are ready to adopt a new product or service. The adoption or rejection of an innovation begins when "the consumer becomes aware of the innovation" (Rogers and Shoemaker, 1971). Howard and Moore (1982) emphasized that adoption "consumers must become aware of new brand." Lack of awareness is the most important factor that negatively affect Internet banking adoption (Sathye, 1999). In this same context we are able to argue that if the average Malaysian consumers not adopting Internet banking services due to they unawareness of the availability of such a service and / or benefits it offers.

\subsection{Ease of Use}

Cooper (1997) identifies "ease of use" as on of the three important characteristics from customer's perspective for adoption of innovative service. Dover (1998) and Daniel (1999) studies in USA and UK respectively found that ease of use as one of the factors for customer acceptance electronic banking. In this same context, a study conducted by a company called Cyber Dialogue has revealed that as many as 3.1 million USA adults have discontinued their use of online banking because they found the service too complicated or were dissatisfied with the level of customer service. Katz and Aspden (1997), Walis (1997) and Mols (2000) suggested that it is crucial for the Internet to be easy to use to increase the adoption rate Internet banking. Scarbrough and Corbett (1992) identified the understanding of consumers as an important element for the diffusion of innovation technology.

For successful implementation of Internet banking, banks must ensure that the services are simple, easy and of sufficiently high quality to ensure customer satisfaction in order to maintain online customers.

\subsection{Security}

Security is one of the very important factors in determining the decision of consumers to use Internet banking. In a study ABF (1997) found that security concerns are keeping both consumers and bankers away from Internet banking. The Walls report (1997) also reported that unless security is improved, more households would be willing to conduct their transactions over the Internet. O'Connel (1997) conducted study in Australia found that security concerns were discovered as the main cause for the slow growth of Internet banking in the country. Polatoglu and Ekin (2001) established risk in terms of financial, physical and social characteristics. In USA, Thorton Consulting (1996) which conducted a survey focusing on banks concluded that 67 percent of US banks feel that "security concerns" is the major barriers for Internet banking. The same results obtained from the study of Booz et al. (1997), reveals that security concern among customers was the top-ranking obstacle for non-adoption of Internet banking in Latin America.

\subsection{Cost}

Price/costs is one of the single most important factor that influences the consumer adoption of innovation. Suganthy et al (2001) found that cost as a characteristics of Internet banking. Two types of costs are involved in the Internet banking, i.e. normal costs associated with Internet activities and second is the bank charge and cost (Sathye, 1999). If consumers are to use new technologies, the technologies must be reasonably priced relative to alternatives (Willis Report, 1997). Otherwise, the acceptance of the new technology may not be viable from the standpoint of the consumer. Virtual Society Project researcher (Buzz, 2000), point out that millions of users are now turning their backs on the Internet due to its limitations and high access charges.

\subsection{Reluctance to change}

Quinn and Mueller (1982) found that human beings try to resist change, especially towards technological innovations. According to Daniel (1999) also stated that there is a high level of customer inertia in changing their established banking arrangements. Sathye (1999) emphasized that customers, particularly the senior citizens, prefer personal interaction and that they have technology phobia. In Malaysia also at the same, bank customers till patronize bank branches and they remain to value personal interactions (Guru et al., 2000).

\subsection{Accessibility}

Finally, availability of access to computers/Internet is a prerequisite for adoption of Internet banking (Sathye, 1999). The more widespread the access to computer/Internet the greater the possibility of use of Internet banking adoption. O, Connell (1996) study found that lack of access to computers as one of the reason for slow adoption of Internet banking. Daniel (1999) study in UK reveals that lack of customer access to suitable PCs as the main reason for low usage of electronic banking. In the same view Ramsay and Smith (1999) found that accessibility as on of the main reasons for non-adoption of Internet banking. 


\section{Research Model and Hypotheses}

The purpose of this study is to test empirically the factors that influence Internet banking by consumers in Malaysia. We used Internet banking as the targeted technology. In this study, we hypothesized that accessibility, cost, reluctance to change, security ease of use, and awareness affect an individual's intention to use Internet banking technology. The research model for this study is shown in Figure 1.

There are six hypotheses in this study.

Hypothesis 1: Awareness positively affects the intention to use Internet banking

Hypothesis 2: Ease of use positively affects the intention to use Internet banking

Hypothesis 3: Security negatively affects the intention to use Internet banking

Hypothesis 4: Cost positively affects the intention to use Internet banking

Hypothesis 5: Reluctant to change negatively affects the intention to use Internet banking

Hypothesis 6: Accessibility positively affects the intention to use Internet banking

\section{Methodology}

\subsection{Sample and Data Collection}

Quantitative analysis was chosen to test the research model, as it is good for measuring how many and in what proportion. The method for collecting empirical data for the statistical analysis was customer survey. An in-depth interview was conducted with ten lecturers from one university before the final survey was conducted in order to identify the key elements to be asked in the questionnaire. Survey questionnaire were sent out to randomly selected business customer from the telephone and business directory using their telephone prefix identifier. The selection process was conducted until a sample of 250 is completed. Then they were contacted over telephone to ensure their participations. Upon obtaining their agreement to answer the survey questionnaire, it was then mailed to them. To ensure the feedback, three subsequent reminders were sent over telephone and the mail after the initial surveys were mailed. Telephone inquiries were conducted only two weeks later as a last resort for those respondents that had not responded.

\subsection{Data collection instrument}

The data for the study was gathered through a structured questionnaire. All variables were operationalized using the literature on online shopping (Sathye, 1999; Cooper, 1997; Katz and Aspden, 1997; Booz et al., 1997; Suganthy et al., 2001; Ramsay and Smith, 1999). The first part of the questionnaire included questions about Internet banking usage habits of the respondents such as preference of Internet banking usage, whether they have Internet access at their firms or not, and their feelings about the Internet banking security. The second part consisted of questions measuring all the variables including two questions which are used to measure the Internet banking. All the questions were utilizing on a Likert scale ranging from $1=$ strongly disagree to $6=$ strongly agree.

The questionnaire was pre-tested within the faculty and was send to three academics who are found to be expert in the field for the purpose of establishing face validity of the items. The aim of the pretest was to prevent any vagueness and misunderstanding with minor adjustment to the wording and sequence of the questions. The revised questionnaire was then administered to respondents with a cover letter explaining the academic purpose of the study. The third part consisted of questions regarding the demographic characteristics of the respondents firms.

All items intended to measure the variables in this study were adopted from previously validated instruments. Regression analysis was used to analyze the data. An exploratory factor analysis was performed with varimax rotation to assess the reliability and validity of the measurement model before the regression analysis.

\subsection{Reliability}

Reliability as suggested by Moore and Benbasat (1991) for the scale and Cronbach's alpha for scale reliability obtained for our sample. The internal reliability of the items was verified by computing the Cronbach's alpha (Nunnally, 1978). She suggested that a minimum alpha of 0.7 sufficed for early stage of research. The Cronbach alpha estimated for awareness was 0.7864 , ease of use was 0.8251 , the security was 0.7713 , cost was 0.7672 , reluctant to change was 0.8623 and accessibility was 0.7551 . Reliability from our sample showed a reasonable level of reliability $(\alpha>0.70)$.

\subsection{Validity}

Factor analysis generates a simple structure or pattern of result that each variable loads highly onto one and only one factor thus creating a data reduction. Rotated Factor Matrix shows the correlations between the variable and the factor. Correlations of 0.4 or less are considered as insignificant and not meaningful as it is of low correlations. In this analysis, variances with loadings of greater than 0.4 are accepted and the factor loadings for all items exceeded the minimum value of 0.4 considered for this study. Having minimum factor loadings of 0.4 , it was concluded that the result of the factor analysis suggest that the conditions of convergent and discriminant validity are satisfactory. 


\subsection{Normality of Data and Multi-collinearity}

This study involves a relatively large sample (200 respondents) and therefore, the Central Limit Theorem could be applied and hence there is no question on normality of the data. Two major methods were utilized in order to determine the presence of multicollinearity among independent variables in this study. These methodologies involved calculation of both a Tolerance test and Variance Inflation Factor (VIF) (Kleinbaum et al, 1988). The results of these analyzes are presented in Table 1. As can be seen from this data, i) none of the Tolerance levels is <or equal to .01; and ii) all VIF values are well below 10. Thus, the measures selected for assessing independent variables in this study do not reach levels indicate of multicollinearity. The acceptable Durbin - Watson range is between 1.5 and 2.5. In this analysis Durbin - Watson value of 1.589 , which is between the acceptable ranges, show that there were no auto correlation problems in the data used in this research. Thus, the measures selected for assessing independent variables in this study do not reach levels indicate of multicollinearity

\section{Results}

The survey results show that a large proportion of corporate customers would prefer to use Internet banking instead of the conventional delivery channel $(91.47 \%)$. Only about $8.53 \%$ of the respondents were not keen on the new delivery channel. Respondents who preferred to use Internet banking were local companies with local ownership (50.67\%) and local company with foreign ownership (23.31\%). The companies, which preferred Internet banking, were relatively small in size, having employees numbering 100 and below (39.91\%) and annual revenue of RM10 million and below $(36.32 \%)$.

Almost half of the corporate respondents (112 respondents) are currently subscribing PC banking as offered by the local banks. Out of this $64.13 \%$ of them are quite comfortable with the services provided through this channel. Most of the corporate customer subscribing PC banking services (82.06\%) felt secure using the service while 3.58\% felt unsecured.

Most of the respondents who preferred Internet banking already have Internet access in their organization (95.96\%) and had come to know of the Internet banking through books and magazines $(48.87 \%)$ and advertisement from the mass media (41.70\%). More than sixty percent of (69.95) indicated that they would switch to Internet banking when the local banks offer the service. Most of the respondents also agreed that employees must be empowered to act on behalf of the companies for transactions conducted online $(52.46 \%)$ if the organization were to use this new delivery channel.

\section{Hypotheses Testing}

The strength of the proposed relationship was assessed using the respective statistical analyses summarized in Tables 2 .

\section{Hypothesis 1: Awareness positively affects the intention to use Internet banking}

Awareness is the important factor that affects Internet banking adoption. The multiple regression result shows awareness have beta $=.239 ; \mathrm{p}$-value $=.001$. The results prove that, the null hypothesis that there is no relationship between awareness and Internet banking adoption could be rejected. Looking at the results obtained, it can be concluded that all the respondents in our survey are familiar about Internet banking. Thus, most common source of information to corporate customer seems to be the mass media (TV, Radio, Newspapers). The second most common information provider for Internet banking to the corporate customer are bank personnel and from word of mouth through friends and relatives.

\section{Hypothesis 2: Ease of use positively affects the intention to use Internet banking}

The results of this study show that the association between ease of use and Internet banking adoption is not significant. The results of this study (please refer Table III) show that there is no significant association between ease of use and Internet banking adoption. The hypothesis 2 could be rejected. It can be concluded that corporate customer found Internet banking is complex procedure.

\section{Hypothesis 3: There is a significant relationship between security and Internet banking adoption.}

Table III shows that the association between security and Internet banking adoption is significant at 0.05 level whereby the analysis result showed the beta $=-0.133$ and $\mathrm{t}$-value $=-2.220(\mathrm{p}=0.027)$. This implies that users are still doubtful of the confidentiality and safety of the technology. The support for hypothesis 3 reflects similar arguments in previous studies (Suganthy, 2001; O’Connel, 1997; Cooper, 1997; Ramsay and Smith, 1999; Guru et al., 2000) who found that security have greater impact on the adoption intent of Internet banking. This factor is a potential impediment to consumers transacting through Internet. This further confirmed the findings of Booz et al., (1997).

\section{Hypothesis 4: Cost positively affects the intention to use Internet banking}

The cost is another important factor that has significant effects on Internet banking. Referring to Table III, the fourth hypothesis tested the relationship between cost and Internet adoption intention. The regression result (beta $=.224$, $\mathrm{t}$-value $=2.992, \mathrm{p}$-value $=0.003)$ indicates that the association between cost and Internet banking adoption is significant at 0.01 level $(\mathrm{p}=0.003)$. 


\section{Hypothesis 5: Reluctance to change significantly affects the intention to adopt Internet banking}

Consumers are ready to adopting Internet banking from the conventional banking method. The results of this study show that the association between reluctance to change and Internet banking adoption is not significant. The multiple regression result shows reluctance to change have beta $=.139 ; \mathrm{p}$-value $=.072$. The results prove that, the null hypothesis that there is no relationship between reluctance to change and Internet banking could not be rejected. This is manifested in the finding, which shows that these customers have the tendency to deal with technology base banking system. This might be due to the advantage of being able to be a part of a meaningful personal relationship while such a thing does not happen through traditional banking. For example, in certain banks, they have priority banking consumers where valued customers are treated personally be tellers. This makes customers feel important to the bank, and therefore leads to loyalty towards the bank.

\section{Hypothesis 6: Accessibility significantly affects the intention to adopt Internet banking}

The findings also show that accessibility to computers and the Internet have influence their decision to adopt Internet banking. The relationship between accessibility and Internet banking adoption is significant and findings show that accessibility has a positive relationship with Internet banking adoption intentions (beta $=.303$, p-value $=.000$ ). One possible reason is that due to the support by the government and also cheaper cost of computer and Internet connectivity for Malaysians, most of the respondents already own computers and also have Internet access.

\section{Limitation of the study}

In this study, there are some limitations which are inevitable. They are as listed below:

Respondents were only selected from the Klang Valley. They might not represent the entire Malaysian business peoples. In order to get a more reliable representation, respondents should be gathered from all states around Malaysia.

This research managed to responses from 223 corporate customers. Their response might not reflect the actual perceptions and opinions of Klang Valley customers. A larger set of sample should be selected if more reliable results were to be obtained.

The opinions of bankers are not taken into consideration in this study.

\section{Recommendations}

This study makes significant contributions to knowledge in relation to customers' perception of factors affecting Internet banking adoption. Furthermore, it also provides an insight into the customers' needs and wants which may be essential for bankers in order to provide better services to customers. In the light of these findings, several recommendations will be made which may be useful for bankers and other related authorities.

Banks should make their customer more aware of their new products or services, in this, Internet banking, to encourage higher adoption rate. They can do so by having seminars, exhibitions or giving free-trial periods to allow customers to evaluate their new inventions. Besides that, education and publicity through mass media will also prove to be effective.

Banks should take security of their Internet banking sites into serious consideration since fraud and websites hacking still haunt most of the customers. Perhaps they can implement more advanced encryption methods and build stronger firewalls to prevent security infringement. Government authorities like Bank Negara Malaysia (BNM) can also play their role by issuing statements which reassure customer that the government recognizes Internet banking as secure.

Internet banking sites should be made as user-friendly as possible as not many consumers are familiar with computer and the Internet, especially the older generation. Providing online help and giving customer the choice of their preferred language will ease their transactions.

In order to receive greater response towards Internet banking, it is recommended that bankers target their promotional activities towards those in the younger business personnel who are computer literate, well educated and are quite well to do as they seem to be the most likely users of Internet banking as indicated in this study.

If possible, banks should not charge customer for their Internet banking services. This is because users have to incur other costs. However, if this does not appear to be feasible, they would have to make sure that the costs of transacting manually does not exceed the costs of Internet banking.

Despite all the frenzy about Internet banking, bank should not neglect their branch networks. Although these branches will play fewer roles in the future, they will still be needed in selling products and services where face-to-face communication is vital. Besides that, they are the only options of cash withdrawals and deposits.

\section{Conclusions}

The main objective of this study is to identify the factors affecting the adoption of Internet banking by corporate customer in the Klang Valley in Malaysia. This research able to identify that for the business people, awareness is the most important and security is seen as the least important and ease of use and reluctant to change are not important 
factors in influencing their adoption rate. This might be due to the fact that the users still think using Internet banking are complicated process. Almost all banks in Malaysia are providing advertisement through all types of channel. Even banks also communicating with their existing traditional customers regarding the online banking facilities provided by them. The only thing that deters them from using the online banking service is their reluctance to embrace delivery channel. This shows that, generally most business peoples are already aware of the service. In order to ease transactions over the Internet, customers would prefer banks to offer online help in circumstances where they experience any difficulties. Business customers feel that online transactions are not secure enough; and they are not willing to use it.

\section{References}

ABF. (1997). Banks Approach Market with Caution, Australian Banking and Finance, 6(13), 9-11.

Bakos, J.Y. (1991). A Strategic Analysis of Electronic Marketplaces, MIS Quarterly, (September), 295-310.

Baldock, R. (1997). The Virtual Bank: Four Marketing Scenarios for the Future. Journal of Financial Service Marketing, 1(3), 260-268.

Birch, D. \& Young, M.A. (1997). Financial Services and the Internet- What Does Cyberspace Mean for Financial Services Industry? Internet Research: Electronic Networking Applications and Policy, 7(2), 120-128.

Booz, Allen \& Hamilton. (1996). Internet Banking: A Global Study of Potential, Booz, Allen and Hamilton Inc. New York, NY.

Chan, L.M. (2001). Is Online Banking Safe, the Star (February), 42.

Cooper, R.G. (1997). Examining Some Myths About New Product Winners, in Katz, R., ed., The Human Side of Managing Technological Innovation, Oxford, pp. 550-560.

Cronbach, L. (1970). Essentials of Psychology Testing, Harper and Row, New York.

Daniel, E. (1999). Provision of Electronic Banking in the UK and the Republic of Ireland. The International Journal of Bank Marketing, 17(2).

Davidson, J. (1998). NAB Wakes Up to Online Banking, Australian Financial Review, (July), $16,34$.

Dover, P.A. (1988). The Effect of Technology Selection on Consumer Adoption of the In-home Computerized Banking. International Journal of Bank Marketing, 2, 31-37.

Guru, B.K., Vaithilingam, S., Ismail, N., \& Prasad, R. (2000). Electronic Banking in Malaysia: A Note on Evolution of Services and Consumer Reactions. Journal of Internet Banking and Commerce, 5(1).

Howard, J. \& Moore, W. ((1982). Changes in consumer Behavior Over the Product Life Cycle, in Tushman and Moore, ed.. Readings in the Management of Innovation, Pitman, 128.

Jeon, L. \& Rice, W.P. (1997). From Web Strategy to Implementation at Liberty Financial companies, in Cronin, M.J., ed., Banking and Finance on the Internet, John Wiley \& sons, New York, NY, 107-136.

Katz, J. \& Aspden, P. (1997). Motivations for and Barriers to Internet Usage: Results of a National Public Opinion Survey. Internet Research: Electronic Networking Applications and Policy, 7(3), 170-188.

Malone, T.W, Yates, J., \& Benjamin, R.I. (1989). The Logic of Electronic Markets. Harvard Business Review, (May-June), 166-172.

Mols, N.P., Bukh, P. \& Nielsen, J. (1999). Distribution channel Strategies in Danish retail Banking. International Journal of Bank Marketing, 27(1), 37-47.

Nunally, J.C. (1978). Psychometric Theory. $2^{\text {nd }}$ Edition, McGraw Hill, New York, NY.

O’Connell, B. (1996). Australian Banking on the Internet- Fact or Fiction? The Australian Banker, (December), 212-214.

Pang, J. (1995). Banking and Finance in Malaysia, Federal Publications Sdn Bhd. Malaysia.

Parisa, A (2006). Adoption of e-Banking Services by Iranian Customers, unpublished Msc thesis. Lulea University of Technology, Division of Industrial Marketing and E-Commerce.

Peters, L. (1998). The New Interactive Media: One-to-one, But to Whom? Marketing Intelligence \& Planning, 10(1), 22-30.

Quinn, R.B. \& Mueller, J.A. (1982). Transferring Research Results to Operations, in Tushman and Moore, ed., Readings in the Management of Innovation, Pitman, M.A, pp. 62.

Ramsay, J. and Smith, M., (1999) Managing Customer Channel Usage in the Australian Banking Sector. Managerial Auditing Journal, 14(7). 
Rogers, E.M. \& Shoemaker, F. (1971). Communications in Innovation, Free Press, New York, NY.

Sathye, M. (1999). Adoption of Internet Banking by Australian Consumers: An Empirical Investigation, International Journal of Bank Marketing, 17(7), 324-334.

Scarbrough, H. \& Corbett, J.M. (1992). Technology and Organization Power, Meaning and Design, Routledge, London, 147.

Thorton Consulting (1996). Internet Banking: A Success. Australian Banking and Finance, (July), 5(13), 2.

Wallis Report (1997). The Financial System Inquiry Final Report, AGPS, Canberra.

Table 1. Test of Collinearity

\begin{tabular}{ccc}
\hline Variable & Tolerance & VIF \\
\hline Awareness & .471 & 2.123 \\
Ease of use & .901 & 1.110 \\
Cost & .375 & 2.663 \\
Security & .589 & 1.698 \\
Reluctance to change & .355 & 2.814 \\
Accessibility & .349 & 2.868 \\
\hline
\end{tabular}

Table 2. Regression Results

\begin{tabular}{|c|c|c|c|}
\hline Variables & Beta & t-value & p-value \\
\hline Constant & & 2.086 & .038 \\
\hline Awareness & .239 & 3.572 & .000 \\
\hline Ease of use & .034 & .695 & .488 \\
\hline Security & -.133 & -2.220 & .027 \\
\hline Cost & .224 & 2.992 & .003 \\
\hline Reluctance to change & .139 & 1.806 & .072 \\
\hline Accessibility & .303 & 3.893 & .000 \\
\hline
\end{tabular}




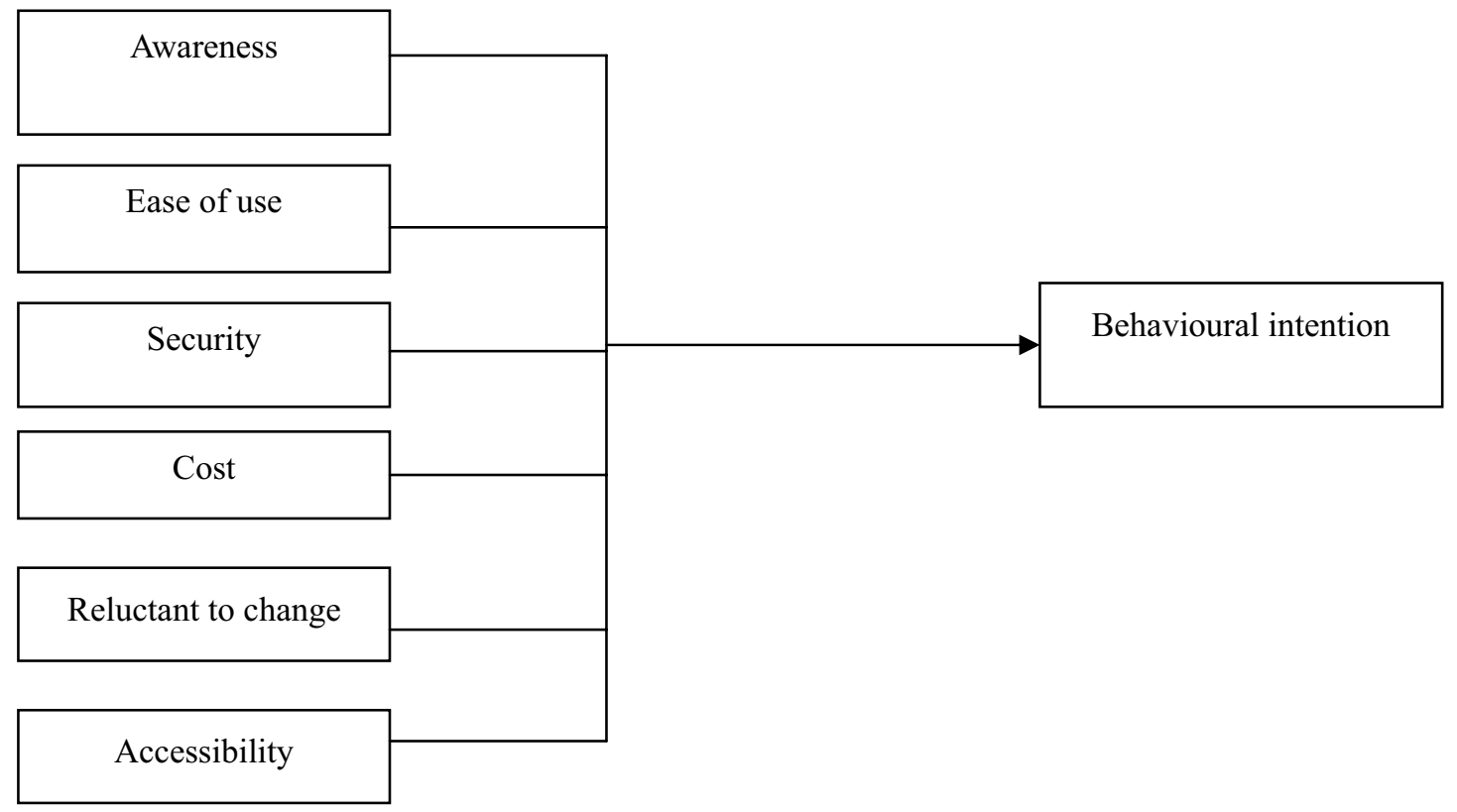

Figure 1. Research Model 